\title{
Post-conviction disclosure in England and Wales: Could conviction integrity units (CIUs) modelled on those in the USA be the way forward?
}

Marika Henneberg, University of Portsmouth

\begin{abstract}
Conviction integrity units (CIUs) operate out of a small number of prosecutors' offices in the USA, and these have since 2007 contributed to several exonerations. In England and Wales, there are obstacles in place that prevent post-conviction disclosure for virtually anyone other than the Criminal Cases Review Commission (CCRC), the body that in effect screens cases for the Court of Appeal. The article examines whether CIUs modelled on those in the USA could be the way forward to help those who have been wrongfully convicted. It is concluded that such units could be useful in England and Wales, and may benefit from being run by a publically elected post similar to the Police and Crime Commissioners (PCCs) implemented in 2012, as this would ensure greater democratic governance and oversight. It is further concluded that improved third party access to post-conviction disclosure is urgently needed.
\end{abstract}

Keywords: criminal appeals, post-conviction disclosure, conviction integrity unit, open justice, wrongful conviction, miscarriage of justice

\section{Introduction}

In England and Wales, it is common to criticise various aspects of the criminal justice system in the USA. This has ranged from controversies around race inequalities, the use in some states of the death penalty, stand your ground laws, the disproportionally large number of inmates and prison overcrowding, to name a few. However, some criminal justice initiatives have also been copied and implemented in England and Wales, such as the attempt to create a system of innocence organisations, very loosely modelled on the original Innocence Project set up by Barry Scheck and Peter Neufeld at Cardozo School of Law (New York) in 1992.

Today there are non-governmental innocence organisations (IOS) in most US states, often (but not exclusively) operating out of law schools. These organisations represent defendants who claim that they are factually innocent and they often form an important part of teaching and learning at the law schools running them. These innocence organisations can be seen as successful as over twenty percent of the exonerations from 1989 and onwards listed on the National Registry of Exonerations (NRE), have involved such an organisation

(NRE, 2018a).

More recently, a relatively small number of prosecutors' offices in the USA have created conviction integrity units (CIUs), sometimes also known as conviction review units, to 
examine cases post-conviction. The individual units have had varying success, but their overall importance should not be under-stated, as roughly ten percent of all the exonerations listed by the NRE from 1989 to 2018 have involved a CIU (NRE, 2018a). However, the NRE also acknowledges that CIUs and IOs are not the only settings within which police and prosecutors work to rectify wrongful convictions (NRE, 2015). Although CIUs and IOs are known to cooperate, and therefore overlaps in the data can be expected, it is clear that these bodies have a significant impact on the ever-increasing number of exonerations in the USA. Whilst far from perfect, one reason why such post-conviction review bodies are as successful is that there is that post-conviction disclosure seem to work better in the USA than it currently does in England and Wales.

In England and Wales there are solid obstacles to post-conviction disclosure and access, and this must be seen counterproductive to justice (Henneberg, 2017). The situation has become so dire that a group of concerned lawyers, journalists and academics launched an 'Open Justice Charter' in January 2017 (Bowcott, 2017). In particular, there is a lack of access to recordings of court proceedings, police documentation, physical exhibits for scientific testing, and materials obtained or produced by the post-conviction review body the Criminal Cases Review Commission (CCRC) (Bolton et al., 2017). With reference to the absurd situation produced by the lack of post-conviction access, English lawyer and founder of Innocence Project New Orleans, Emily Bolton, said that "I'd rather be wrongfully convicted in New Orleans [USA] than New Malden [England]" (Burley, 2017).

Established under the Criminal Appeal Act 1995, the CCRC is an independent body that on 1 April 1997 took on the responsibilities for reviewing alleged or suspected miscarriages of justice that has occurred in England, Wales and Northern Ireland (Naughton, 2010a). Prior to this, the Criminal Case Unit of the C3 Division of the Home Office carried out such investigations and the Home Secretary had the power to refer cases to the Court of Appeal (Criminal Division) (CACD). According to Roberts and Weathered (2009: 48), there was a "need for such investigations to be carried out independently of the executive". Notable cases such as the IRA pub bombings in Birmingham and Guildford in 1974, that led to the wrongful convictions of two groups of men referred to as the Birmingham Six and the Guildford Four, acted as a catalyst for this change.

Since 1997, a convicted person has to apply to the CCRC, pretty much the only body with the necessary post-conviction access to any material needed, to have a look at their case. Then the CCRC will decide whether or not to refer the case to the CACD for their consideration, using the highly criticised 'real possibility' test. Statistics from the CCRC provide clear evidence of just how difficult it is to obtain post-conviction relief in England and Wales. Out of 23,366 completed applications at the end of 2018, the CCRC had referred 653 cases to the court and of those 436 cases were successful on appeal (CCRC, 2018a). However, as an applicant to the CCRC can ask to have either their conviction or sentence, or both, looked at, not all of the successful appeals involved wrongful convictions (i.e. someone convicted for a crime they did not commit).

The limitations on post-conviction access for anyone apart from the CCRC, has also meant that innocence organisations have not been very successful in England and Wales. An 
umbrella organisation was set up in 2004, the Innocence Network UK (INUK), but it came to a halt in 2014. Whilst a small number of innocence organisations still operate out of universities, there have been few success stories in this jurisdiction. It is clear that England and Wales have fallen behind the USA when it comes to possibilities to conduct postconviction reviews by third parties (including an applicant's lawyers, innocence organisations and others), and that this is to the detriment of those who have been wrongfully convicted.

However, before discussing England and Wales and the USA in detail, it is important to acknowledge how some specific limitations of comparative research affect the discussion in this article. Pakes (2017:3) suggests that, "Comparing is not easy" when it comes to the academic endeavour of comparative criminal justice, however, there is a lot to learn from jurisdictions other than one's own. Whilst England and Wales and the USA utilise adversarial systems that historically developed out of the same legal roots, today there are significant differences between these systems.

First, England and Wales is one single jurisdiction, made up by two nations. Referring generically to the USA, on the other hand, is problematic, as it comprises of $\mathbf{5 0}$ individual states with their own legal systems as well as a federal system. It is therefore somewhat awkward to do a side-by-side comparison of England and Wales and the USA as so many variations exist within the USA itself. However, jurisdictions within the USA do provide invaluable insights of relevance to this article, which can be compared to the experience in England and Wales.

Secondly, the article does not intend to suggest that what applies in one individual state of the USA applies throughout the country. This is particularly true when it comes to CIUs, as there is only a very small number of such offices across the USA. In fact, only a few elected District Attorneys have opted to create a $\mathrm{CIU}$, which means that generalisations must be made with extreme caution, as these are not representative of the USA as a whole.

Thirdly, the USA is in many ways a more punitive country than England and Wales. For example, the death penalty is available as a punishment in more than half of the jurisdictions within the USA (Death Penalty Information Center, 2019), and in addition, extremely long prison sentences are common (Welch, 2011). This level of punitiveness, where the stakes for individuals are so high, may go some way towards explaining why IOs are such an integral (and seemingly successful) part of the post-conviction arena, and also why post-conviction disclosure appears to be better in the USA than in England and Wales. With that being said, there is still a need for much better post-conviction disclosure in England and Wales and the USA.

The current situation in England and Wales is examined in part two of this article, where controversies with post-conviction access are addressed. This is followed in part three by a brief outline of CIUs in the USA. In part four, the article then examines whether CIUs modelled on those in the USA could be the way forward, and whether the creation and implementation of such units would overcome any of the issues identified as problematic in 
part two. The article does not intend to offer package solutions to the practicalities of setting up such units, as the focus is mainly on post-conviction disclosure.

The article concludes that smaller CIUs, set up in the 14 Crown Prosecution Service (CPS) areas, may be useful provided that issues with independence and post-conviction access are properly addressed. In addition, a new layer of checks and balances could be provided through the creation of a publically elected post to run the CIU in each of the 14 CPS areas. Such elected posts could be similar to the Police and Crime Commissioners (PCCs), introduced in England and Wales in 2012 to hold police forces to account for their performance. This would provide new oversight as decisions and steps taken by the police and the CPS (including in relation to disclosure) could be scrutinised and questioned. Furthermore, this could arguably strengthen the integrity of the criminal justice system as a whole, as there would be greater democratic governance and accountability. However, it is also concluded that better third party access to post-conviction disclosure is urgently needed in order for convicted individuals to even be able to take the necessary first steps towards an appeal - such as applying to the CCRC or making contact with a CIU.

\section{Issues with post-conviction disclosure in England and Wales}

A basic overview of the criminal appeal system in England and Wales needs to be given so that ongoing critical issues surrounding post-conviction disclosure can be explained in context. In England and Wales, a convicted person can apply for leave to appeal (i.e. asking the court's permission to appeal) which, after a crown court trial, has to be filed within 28 days of a conviction, or, if later than 28 days, an application for leave to appeal out of time needs to be submitted. A single judge will consider the application, and if the single judge refuses leave, this decision can be appealed to the full court of three judges (Roberts, 2017). As can be expected, it is unlikely that a lot of new substantial evidence will have come to light in such a short amount of time and, therefore, direct appeals tend to focus on points of law, procedure or process, rather than claims of innocence (Ashworth and Redmayne, 2010: Roberts, 2017). These direct appeals can normally be heard by the Court of Appeal (Criminal Division) (CACD) relatively quickly, typically within a year of the conviction. If no direct appeal is filed at the time, the defendant can apply for leave to appeal 'out of time' at a later stage. However, following an unsuccessful direct appeal (within or out of time), or an unsuccessful application for leave to appeal, a defendant must then apply to the Criminal Cases Review Commission (CCRC) - the body that reviews cases and decides whether or not a case should be referred to the CACD for their consideration.

Section 23(1) of the Criminal Appeal Act 1968 gives the CACD a general discretion to admit evidence "if they think it necessary or expedient in the interest of justice". Under Section 23(2) the evidence need to be capable of belief (credible), capable of forming a ground for appeal (this may include new legal arguments or errors in law/procedure), and a reasonable explanation for the failure to adduce the evidence at trial if it had been available to the defence. The CACD will consider the admissible evidence and decide, in accordance with Section 2(1) of the Criminal Appeal Act 1995, whether they think that the conviction is 
unsafe, in which case the appeal will be allowed, or whether the conviction is safe, in which case the appeal will be dismissed. As the focus is on the safety of the conviction, the court "does not need to be satisfied that the applicant is innocent" (Hoyle, 2019:921).

Applicants to the CCRC are encouraged to use their standardised application form which includes the following: "Tell us what you think went wrong with your case and what is new" (CCRC, N.D.). In other words, with the CCRC's application form the person is asked to provide this information before the CCRC even looks at the case. This is very problematic as there is a general lack of post-conviction disclosure to virtually anyone other than the under-resourced CCRC itself (Bowcott, 2018; CCRC, 2017/18; Green, 2010). The CCRC's allocated budget, which has shrunk on an annual basis for the past fifteen years, can be used to illustrate the seriousness of the situation. The CCRC received $f 7$ million in 20032004, this was reduced to $f 6.5$ million in 2009-2010, and down to $f 5.6$ million in 2017-2018. The number of applications to the CCRC, on the other hand, keeps rising, and it has been noted that for every $f 10$ that the CCRC had to spend per case ten years ago, there is only about $f 4$ available today (Bowcott, 2018).

The Criminal Appeal Act 1995, Part II, outlines the procedures and decision-making processes at the CCRC. Twelve Commissioners, approximately 30 case review managers, a legal advisor and an investigations advisor, along with administrative and executive support, make up the staff of the CCRC. Importantly, the CCRC can require disclosure of evidence from public bodies (Section 17) and, since 2016, also from private bodies (Section 18A). This puts the CCRC in a superior position when it comes to post-conviction disclosure.

Once an application has been made, administrators check eligibility and may obtain relevant supporting documents. This is followed by a screening process (a superficial review) by Commissioners and case review managers and nearly half of the applications are closed at this stage and the applicant is sent a 'Statement of Reasons' document, explaining why the case will not be subject to any further work. An application that gets through this first screening process is then allocated to a case review manager who will conduct a more thorough investigation, which may involve the commission of expert reports and interviews with the applicant and/or witnesses. The case review manager can make a provisional decision about whether to refer the case, but the assigned Commissioner has to approve most key decisions. Curiously, the CCRC's decision-making procedure allows the assigned Commissioner to make a unilateral decision to not refer a case to the CACD. However, a committee of a minimum of three Commissioners must agree before a referral to the CACD is made. In other words, the CCRC is testing a case in front of a bench of at least three Commissioners before a referral is even made, which can be seen as trying to second-guess the CACD.

In accordance with Section 13(1) of the Criminal Appeal Act 1995, the CCRC should only refer a case to the CACD where there is a 'real possibility' that the appeal will succeed (i.e. the CACD will determine that the conviction is unsafe). This 'real possibility' test has been described as "a unique threshold in the criminal process" (Kerrigan, 2010: 168), and criticism has been levelled at the commission for trying to second-guess what the CACD may think of a case and adopting an approach that is far too risk averse as a result (see e.g. Kerrigan, 
2010; Naughton, 2013). Ironically, it has been noted that the case of the Birmingham Six, which acted as a catalyst for the creation of the CCRC, would most likely not pass the 'real possibility' test for the CCRC to refer it to the CACD (Naughton, 2010c). The combination of the CCRC's under-resourcing and risk aversion is detrimental to many wrongfully convicted applicants.

Non-disclosure of evidence has been described as "a potent source of injustice" ( $R \vee$ Ward [1993] 1 WLR 619) and, although proposed changes to pre-trial disclosure contained in the Criminal Procedure Rules looked set to improve things (see e.g. Murray, 2016), the last couple of years have shown that pre-trial disclosure is still very problematic (this is further outlined in part four). In comparison however, post-conviction disclosure has always been very limited. The case of Kevin Nunn, which has been on a legal obstacle course since his conviction for murder in 2006 based only on circumstantial evidence, illustrates this very well (Henneberg, 2017).

The burnt body of Nunn's girlfriend had been found by a river in 2005, and there was no physical evidence that could directly point to a suspect. Four sperm cells were found on the victim, but it was not possible to obtain a DNA profile from these at the time, as the technology to do so did not yet exist. In addition, controversial suggestions were made that the sperm cells were the result of secondary transfer that had occurred when the victim had used a male changing room at a sports centre earlier in the day (McCartney and Speechless, 2015). The sperm cells were retained to enable future DNA testing. Nevertheless, over the years Nunn has been refused leave to appeal and later on, following an application to the CCRC, the relevant police force refused to allow access to physical material for further scientific testing. A judicial review followed and finally an appeal was made to the UK Supreme Court (UKSC), a court that only rules on points of law, it does not decide on facts, for them to determine the extent of post-conviction disclosure and access to material under the current laws.

In 2014, the UKSC held that post-conviction disclosure should occur when material comes to light after the conclusion of proceedings, that cast doubt upon the safety of the conviction (unless there is a good reason why it should not be disclosed), and in addition, where there exists a real prospect that further enquiry will reveal something that may affect the safety of the conviction ( $R \vee$ Nunn (on the application of Suffolk Constabulary \& Anor [2014] UKSC 37, para. 30,41$)$. In relation to Nunn, the UKSC concluded that, "On the limited information presently available it seems unclear that a real prospect is established of material emerging affecting the safety of the conviction" (para. 43). It also held that any further request for access to the sample should be tested on those principles, in the first instance by the police and if necessary by the CCRC.

The Nunn ruling has made it clear that the system is very hesitant to allow post-conviction inquiries (or disclosure requests) to be used for general 'fishing expeditions' by applicants, their lawyers and third parties such as innocence organisations. In particular, the police and the Crown Prosecution Service (CPS) may be reluctant to open up their past actions to scrutiny within the context of a post-conviction inquiry, and may vehemently resist any such request. McCartney and Speechless (2015:124) state that the Nunn ruling "makes it clear 
that the Supreme Court does not consider post-conviction non-disclosure as posing equal risk, because the prisoner has already had the benefit of a full trial (and often, appeal)".

The CCRC provides the safety net in case there is a dispute, it "does not, and should not; make enquiries only when reasonable prospect of a conviction being quashed is demonstrated. It can and does in appropriate cases make enquiry to see whether such a prospect can be shown" (Nunn, para. 39). However, McCartney and Speechless (2015: 125) have described the CCRC as the "final arbiter on disclosure requests", which creates a reality where applicants who are unable to show grounds for an appeal may be denied access to the very material that could provide those grounds, by the very body that is supposed to be a watchdog for miscarriages of justice. The CCRC may in effect sometimes add further to the problems, as during their review of a case, they may obtain or produce materials that are then not disclosed to the applicant or their representatives. Arguably, when an application is rejected by the CCRC, the applicant and their representatives should have access to the material used by the commission for them to come to that decision, along with clear explanations for why such a decision has been made (Bolton et al., 2017).

The lack of disclosure to third parties means that it is virtually impossible for a defendant or their representatives (including lawyers) to get hold of material needed to put a persuasive CCRC application together. This problem is further exacerbated by the fact that there are few places that a wrongfully convicted person can turn to for help to work on their CCRC application (Robins, 2018a). The former Chairman of the CCRC, Richard Foster (in post 20082018) confirmed on several occasions that the commission is more likely to pick up a case where the application has already had legal input (such as at the Criminal appeals in the age of austerity conference at City Law School, London, 25 November 2015). This clearly contradicts the intended ethos of the CCRC, namely that it should be easy for a defendant to apply to have their case looked at by the commission.

In fact, research by the University of Warwick (Hodgson and Horne, 2009) looked at applications that were closed by the CCRC between 1 January 2001 and 31 December 2007, to determine their progress through the CCRC screening and decision-making processes. The findings show that there was a significant difference throughout, between unrepresented versus represented applicants. There was a 50.8 percent chance of an unrepresented case being closed due to it being ineligible in the early stages, compared to an 18.4 percent chance for the represented cases, and there was only a 2.1 percent chance of an unrepresented case being referred to the CACD, compared to 7.6 percent for the represented cases (Hodgson and Horne, 2009:12).

In 2006, the CCRC indicated that between 40 and 50 percent of applicants were legally represented (Hodgson and Horne, 2009:11). Today the number of applicants that apply without the help of a lawyer has risen to almost 80 percent (CCRC, 2017/18:11). Judging from CCRC's extremely low referral rate, a miniscule 0.77 percent of cases were referred to the CACD in the period 2016-17, it is clear that even the vast majority of applications that had legal input were rejected by the CCRC (Allison et al., 2018). Nevertheless, the CCRC has suggested that their extremely low referral rate can in part be blamed on a lack of lawyers willing to work on appeal cases (Robins, 2018a). 
Legal aid rates have been significantly reduced. Robins (2018b) states that the Ministry of Justice's budget will have shrunk by 40 percent in the last decade - from $£ 9.3$ billion in 2010-2011 to a predicted $\mathrm{f5.6}$ billion in 2019-2020. Whilst this reduction affects the sector in general, legal aid lawyers have not had an increase in their fees for 20 years, and had an 8.75 percent reduction to their fees in 2014 (Robins, 2018b). Many law firms have decided to close their criminal law departments and nowadays there are only a few lawyers who are prepared to take on such poorly paid cases (Bowcott, 2015; Robins, 2016). This is problematic as many defendants have to rely on legal aid to cover the cost of a solicitor working on their CCRC application. Complex cases of alleged wrongful conviction, such as cases where the conviction was entirely based on circumstantial evidence, often requires numerous hours of work to even identify potential grounds of appeal. Such extensive work is not going to be covered by legal aid (see e.g. Justice, 2011: 50-51). This may, ironically, mean that solicitors dealing with legal aid cases may choose not to take on a case unless there are already some clear grounds of appeal and only minimal investigation or engagement on their behalf is needed (Henneberg, 2017). A wrongfully convicted person will effectively be shut out of the appeal system unless they can pay privately for a lawyer to work on their case, or they qualify for legal aid, and, in either case, that they can show new evidence that is compelling enough for the CCRC to pick up (and refer) the case. This is problematic as there is a lack of third party access to post-conviction disclosure.

Controversial problems with post-conviction disclosure and access exist. Some of these problems were addressed in the Open Justice Charter in 2017 (Bolton et al., 2017), where a group of concerned lawyers, journalists and academics suggested that improvements to current policies and practices on post-conviction access were urgently needed. Five main areas were highlighted, and these were access to: recordings of court proceedings; police documentation; physical evidence for scientific testing; prisoners; and materials obtained or produced by the CCRC. Without better access post-conviction, it becomes very difficult (or even impossible) for those claiming that they have been wrongfully convicted to be able to progress through the appeal system.

Although crown court proceedings are audio recorded in full, these recordings are deleted after an unreasonably short time. In this digital age, this is an inexcusable practice as important verbatim records are lost forever, and Henneberg (2016) called this routine destruction of court material "reckless and irresponsible". Audio tape recordings are destroyed after five years and digital audio recordings after seven years, unless there is a preservation order in place. However, even where the recordings have not been destroyed, the costs of obtaining transcripts are eye watering (some being quoted tens of thousands of British pounds for the full trial). The policy which governs this is the Crown Court Record Retention and Disposition Schedule (drafted in 1972 and updated in 2011), and importantly, this even covers a document known as The Judge's Summing Up (Robins, 2016). This summing up is considered crucial as a starting point for any appeal work and once lost there is no way to recreate it. Henneberg (2017) argued that this destruction of records of court proceedings effectively prevents access to justice post-conviction, it infringes on the rule of law and, furthermore, it creates a lack of transparency and accountability. 
In relation to police documents, materials and physical exhibits retention is a lot better. For example, the National Police Chiefs' Council's retention policy for evidence in a murder case is 30 years (Robins, 2016). However, it must be argued that in order to promote a safer and fairer justice system, post-conviction access to police documentation also needs to be improved. Bolton et al. (2017) recommend that the HOLMES record, an electronic system where all police activity and documentation in a case are listed, should be made available to the defendant, along with the opportunity to request and receive any document listed on HOLMES. This is essential to ensure that there is better transparency, as any decisions and steps taken by the police and the Crown Prosecution Service (CPS) can be scrutinised and questioned. Saunders (2014) argues that unlimited access to case materials would "put prisoners on an equal footing" with the police, but that the police "have no incentive to have a cold case review" where someone claims that they have been wrongfully convicted. The obstacles that need to be overcome after Nunn are apparent, and after the ruling, a popular expression has been used among those practicing in this area of law, namely 'postconviction disclosure? You can have Nunn' (pronounced as 'none'). It must be argued that integrity is compromised in a system that does not acknowledge its own potential fallibility, and the prevention of disclosure of material post-conviction is only adding to this systematic failure.

Finally, even the most basic breakdown of the statistics from the CCRC show that only very few cases progress through the various stages at the CCRC and result in a referral. Naughton (2010b) argues that it is easier for cases involving technical or legal issues to be referred by the CCRC to the CACD, and for these cases to subsequently be quashed on appeal, than it is for someone who claims that they were wrongfully convicted to be referred and have their conviction quashed. Out of 23,366 completed applications, the CCRC only referred 653 cases to the CACD, and of those, 436 cases were successful on appeal (CCRC, 2018a). Whilst the success rate among the referred cases may look promising, only a fraction of these cases involved a person who had been wrongfully convicted for a crime that they did not commit. Many of these cases relate to errors in law or procedure, rather than 'innocence', and some of the cases even relate to appeals of sentence only. However, it must be noted that it may be much easier to prove a legal or technical irregularity rather than to prove innocence, so this category of cases may still include innocent individuals.

In summary, two broad themes have emerged in part two - one relates to the CCRC itself, and the other to third parties working (or trying to work) with criminal appeal cases.

- The CCRC does have superior access to post-conviction disclosure, but it is severely under-resourced (as highlighted, for every $£ 10$ spent on a case in the past there is now only f4). Even if the budget is significantly increased, the CCRC is also criticised for trying to second-guess the CACD with their 'real possibility' test, and that it has become far to risk averse in its approach to referrals.

- There is a lack of third party (including the applicant, their lawyers, and other parties such as innocence organisations) access to post-conviction disclosure, especially after Nunn. There is also a lack of lawyers willing to take on criminal appeal cases, partly due to the fall in legal aid rates. However, even where third parties are willing 
to work pro bono, they cannot do so in an effective manner as the lack of access makes it difficult to work on a client's CCRC application.

The combination of the CCRC being under-resourced and risk averse on the one hand, and the lack of third party access and people willing and able to help potential CCRC applicants with their applications on the other hand, is very problematic. It has been proven that those applications that have had legal representation or input statistically do better in the CCRC's screening and decision-making processes. The fact that 80 percent of applicants to the CCRC in recent years apply without having had any legal input in their applications, may go some way towards explaining why more cases do not progress past the initial stages of review.

It is time to start a dialogue about potential alternatives to the CCRC, as those who have been wrongfully convicted appear to be seriously disadvantaged by the current system. It would be valuable to discuss conviction integrity units (CIUs) modelled on those that exist in the USA in this context.

\section{Conviction Integrity Units (CIUs) in the USA}

In the past fifteen years, a small number of District Attorney's offices in the USA have created conviction integrity units (CIUs), tasked to conduct fact-based reviews of convictions where there are plausible allegations of factual innocence. The first CIU was created in Santa Clara, California, in 2004. Others have since been created for example in Dallas County, Texas, in 2007, Harris County, Texas, in 2009, Cook County (Chicago), Illinois, in 2012, and Kings County (Brooklyn), New York, in 2014 (see Hollway, 2016:15). However, some units were created but later abandoned as a result of, for example, budget cuts and/or political changes in the county. For example, the first CIU in Santa Clara only lasted for one term (2004-2008), but it was re-established in 2011 (Chandler, 2016). There is no uniform blueprint for CIUs, although the Innocence Project (2015) has developed best practice guidelines. The CIUs that operate at the moment vary in how they are managed, staffed and resourced (Hollway, 2016), which may explain the difference in results achieved to date by individual CIUs. Furthermore, the types of cases that CIUs have looked at also vary between counties, and this contributes to a somewhat sketchy overall picture of their success.

With slight variations, the overarching aim of these CIUs is to conduct a fact-based review of plausible claims of factual innocence, and the majority of cases come to the CIU through the convicted individual (or their representative) making contact with the $\mathrm{CIU}$, asking them to review the case (Hollway, 2016). There are similarities between how, traditionally, innocence organisations (IOs) have acquired clients (on initiative from the convicted person or their representative), and how CIUs and IOs review or screen cases to decide whether to conduct an investigation into the claim of innocence.

A District Attorney (DA) is elected by the voters in their district and serves a four-year term. Whilst a DA's individual reasons for creating a CIU may be both complex and multifaceted, research by Hollway (2016) suggests that an electoral promise, exonerations, and the 
creation of such units elsewhere in the country may feature in this decision making process. It is worth pointing out that campaigns for individuals participating in judicial elections such as the DAs tend to focus on more punitive measures, such as tough on crime policies and increased prison sentences for certain types of offences (Tonry, 2012). Research has shown that judges and prosecutors who are up for election may even become more punitive as the election approaches (see e.g. Huber and Gordon, 2004; Gordon and Huber, 2007;

Bandyopadhyay and McCannon, 2014). What is promising then, is that many of the DAs who have created CIUs ran their campaigns on a platform that included greater accountability and oversight, and made electoral promises to create a CIU to investigate and rectify wrongful convictions (Sklansky, 2017).

The creation of CIUs is encouraging as it provides a diversion from the usual state of affairs, where often "a prosecutor's default posture when faced with a claim of actual innocence is to defend the guilty verdict as quickly and efficiently as possible" (Boehm, 2014: 613). Hollway (2016:13) maintains that the creation of CIUs is "a promising development in the administration of justice", and it shows that prosecutors have a continued obligation to ensure the legitimacy of criminal convictions. Indeed, Fairfax (2012) makes the point that rather than merely seeking victory, prosecutors also have a duty to be fair and to serve the ends of justice and importantly, they have a role to play in reforming the system to make it safer. On that point, Kroepsch (2016) suggests that ethical criticism and technological developments have contributed to a rise in internal programmes within prosecutors' offices, and these programmes have included best practice committees with a front-end approach that aim to prevent future problems from occurring, and CIUs at the back-end of justice where the focus is on reviewing past cases.

The National Registry of Exonerations (NRE) stated that in 2014 CIUs had "accomplished a great deal in a short period of time" (NRE, 2015:11), and this trend was also apparent in 2017 (NRE, 2018b:12). There were 33 CIUs in 2017, a miniscule number in comparison to the 2,300 prosecutor's offices in the USA, meaning that 98.5 percent of offices did not have such a unit (Duffy Rice, 2018). It is promising then, that statistics from the NRE show that CIUs were involved in roughly ten percent of all the cases on its database (293 of the 2296 cases listed as of Nov. 12, 2018), although this is slightly misleading as the NRE lists cases from 1989 onwards, predating the first CIU by fifteen years. From 2004 (when the first CIU was created) to 2018 , there were 1,640 exonerations, with 345 involving a CIU, which is roughly 21 percent of the exonerations. However, the first $\mathrm{CIU}$ exoneration did not occur until 2007, so using instead the 'known' period of CIU exonerations, 2007-2018, the figure is approximately 24 percent (CIUs participated in 345 of 1442 cases). This is significant and the importance of this should not be understated.

Nevertheless, Gould and Leo (2016) were somewhat sceptical about the number of exonerations on the NRE database in their study of wrongful convictions and near misses, claiming that the definition used is vague enough to leave a case eligible for inclusion where the defendant is legally not guilty, but he or she may not necessarily be factually innocent. However, as discussed in part two, this discrepancy is also apparent when looking at the statistics of cases referred by the CCRC to the CACD, as those include a mixture of grounds 
for appeal, including errors in law, process and procedure, and not only cases of 'proven' innocence such as the availability of someone else's DNA. In both jurisdictions, it may be easier to 'prove' that there are legal or technical faults with a conviction rather than that the person is innocent.

CIUs are by no means an easy fix to the problem of wrongful convictions. Gross (2016) notes that the number of known exonerations, although increasing, is still only a fraction of false convictions that occur. Whilst DNA cases have gained attention since the work by the Innocence Project started in the 1990s, these cases are only the tip of the iceberg (Garrett, 2011; Gould and Leo, 2016). The post-conviction process may be more straightforward in cases where technology such as DNA testing can point towards the guilt of another person than where re-examination has to be by other means. However, in both types of cases, new evidence or arguments have to exist and the prosecutor's office must be willing to test the evidence (Moore, 2011).

Pecker (2013:1635) argues that "fresh eyes" are important, and that conflicts of interest must be avoided and recusal rules should apply, so that a different prosecutor than the one securing the conviction reviews any post-conviction claim of innocence. Boehm (2014) suggests that it is crucial to raise awareness of wrongful convictions and foster a culture of seeking innocence (and the truth) in prosecutors' offices. It is hoped that an adequately resourced $\mathrm{CIU}$, that adheres to high standards of ethical obligations, and that is staffed with prosecutors with an understanding of post-conviction claims of innocence, would contribute towards a shift towards more acceptance of post-conviction claims of innocence.

An important part of any post-conviction work towards an appeal is access to relevant material. CIUs have not solved all the problems with post-conviction disclosure, and there are variations between states when it comes to post-conviction disclosure rules. Levenson (2014:548) notes that unless the case involves life without the possibility of parole or a death sentence (where post-conviction disclosure is usually permitted), at state level, there are no automatic rights to disclosure, instead district courts will use their discretion and may only permit this where there is "good reason" or "good cause" to do so. As in England and Wales, however, even where permitted the court may limit the scope of what is disclosed, for example where there is a so called 'fishing expedition', or where the evidence could have been obtained at trial. However, a CIU created within a prosecutor's office should be optimally placed to review any material that the office has, without the need for disclosure to an outside party.

The late Brooklyn DA Ken Thompson created what was possibly the largest CIU to date when he took up office in 2014. This CIU reviewed questionable convictions and upheld the majority of those reviewed, but a total of 24 individuals were exonerated (Brooklyn District Attorney's Office, 2018). For example, in March 2016, Brooklyn man Andre Hatchett was released from prison after serving 25 years for a murder he did not commit. Barry Scheck, co-founder and co-director of the Innocence Project (which collaborated with the CIU to secure Hatchett's release) commented that "We are incredibly grateful to District Attorney Ken Thompson and his conviction integrity unit, without which Mr. Hatchett may never have received justice. This was a cooperative, non-adversarial search for the truth that should be 
a model for all who do this work. We had an information sharing agreement that allowed us access to all police records and the district attorney's file. There was a constant exchange of ideas and suggestions for investigation. Without this cooperation and open disclosure, we would have never discovered the many missteps that revealed Mr. Hatchett's innocence" (Innocence Project, 2016). Arguably, such openness, transparency, and willingness to collaborate with those on the defence side when it comes to reviewing cases postconviction should be the standard, not the exception. The creation of CIUs in 1.5 percent of DA offices is a small step in the right direction, but much more work is needed within the USA as well to ensure that this becomes widespread throughout the country.

Scheck (2010:2256) calls the development of CIUs "an extremely significant first step towards achieving serious quality assurance in the criminal justice system generally". Reviewing the experiences of the CIU in Dallas County, Ware (2012) suggests that faults do not occur in only one place in the criminal justice system, and that reforms are needed throughout. Scheck (2017) argues that within CIUs, prosecutors and defenders can help each other understand the system better and ensure reliable outcomes, providing that openness and transparency is adhered to. Furthermore, this "ought to generate new, constructive, and creative ideas beyond the resolution of the individual cases" (Scheck, 2017: 750). Where errors are detected and analysed, true reform can follow and integrity within the criminal justice system can be strengthened. DAs are well placed to promote better integrity, and CIUs have an important role to fulfil to achieve such systemic change, and may contribute to ending the culture of blame between the different parts of the criminal justice system. To that effect, it would be beneficial to have a CIU in every DAs office in the USA, and arguably, it would be valuable to consider taking such steps in England and Wales as well.

\section{Could CIUs modelled on those in the USA work in England and Wales?}

The two broad themes of problematic issues that were identified in part two in relation to post-conviction disclosure in England and Wales need to be examined alongside the experience of the CIUs in the USA, to address whether or not the creation of CIUs in England and Wales would overcome some or all of these issues. It was concluded that the CCRC lacks adequate resources and that they are too risk averse in their referrals, and that there are few third party actors that can help a prospective applicant to the CCRC with their applications due to diminishing legal rates and barriers preventing post-conviction disclosure (the latter also affecting those prepared to work pro bono).

In any jurisdiction, it is an impossible task to try to find important new evidence needed for an appeal without proper post-conviction access to documents, materials and physical exhibits. It is worth noting that there should be a paper trail (e.g. documents and/or photographs) verifying the existence of any materials and physical exhibits. A lack of disclosure can potentially manifest in multiple ways. For example, consider the situation with ineffective pre-trial disclosure of police and prosecution files in the following scenarios: 
A. There was never a need for document $X$ and it does not exist. This should be relatively clear from the files, if appropriately disclosed.

B. Document $X$ was never created even though it should have been. This may indicate a breach of procedure (whether related to police or prosecution) and this would be possible for the defence to find out before the trial with effective pre-trial disclosure.

C. Document $X$ did exist but was never disclosed pre-trial. Depending on the nature of the document, this may be in clear violation of pre-trial disclosure rules, and effective pre-trial disclosure should have prevented this.

D. Document $X$ was disclosed but was lost from the defendant's case files after trial. Pre-trial disclosure rules may have been adhered to initially, but it is difficult to distinguish this from $B$ and $C$ above.

After an individual has been convicted, post-conviction access to the police and prosecution files is needed to clarify what has happened in scenarios $A, B, C$, and $D$, especially in relation to the violation of applicable pre-disclosure rules. Furthermore, in relation to $D$, the convicted individual should not be penalised for a misfortune that they were not responsible for (such as documents or files being lost). However, in both England and Wales and the USA, restrictions can be placed on post-conviction disclosure, even where granted, especially to avoid so called 'fishing expeditions'. Whilst there may be a need to place some restrictions on items that are sensitive or irrelevant, barriers such as those after Nunn are extremely difficult to overcome. In the USA, the use of open file discovery in some states would appear to be a better alternative, although even this will always be subject to the prosecutor's office having to remove confidential or privileged information (Boehm, 2014).

It is worth considering three alternatives in relation to England and Wales: retaining the CCRC and keeping the status quo; retaining the CCRC but also creating a number of regional CIUs either within the CPS (beneficial for access) or as independent bodies; or, disbanding the CCRC in favour of CIUs either within the CPS or as independent bodies. Depending on how such units are set up, it can be argued that CIUs situated within prosecutors' offices (CPS) in England and Wales would have optimal post-conviction access if they are in-house, thus removing the need to screen and restrict or redact information, and would be in a good position to review contested convictions. However, if CIUs are not part of the CPS and instead seen as third parties, these may be wholly dependent on improved third party access as well in order to work efficiently unless these are given the same powers in relation to disclosure as the CCRC currently have.

It is unlikely, though, that any radical changes will be on the horizon any time soon. In England and Wales, the criminal justice system has endured consistent and severe cuts to its services for the last decade, and as a result, it appears to also have become a political minefield. An illustration of this can be seen in the unwillingness of those in prominent criminal justice positions to acknowledge the effects, whilst in office, that austerity cuts have had on the ability to administer justice fairly, safely and effectively. This has been seen in relation to the front-end of justice (prosecutions) as well as at the back-end of justice (appeals). On the other hand, police chiefs have been very outspoken about the consequences of budget cuts (Dodd, 2018), and the National Audit Office (NAO) levelled 
criticism at the Home Office for failing to even forecast the effect of losing 44,000 police officers and staff, equivalent to 18 percent of its workforce, since 2010 (BBC, 2018; NAO, 2018).

A front-end example of this reluctance to acknowledge the dire state of the criminal justice system relates to the recently departed head of the Crown Prosecution Service (CPS) (who holds the title of Director of Public Prosecution, DPP) Alison Saunders, who was in post 2013-2018. Concerns were raised in the BBC Radio 4 programme File on 4 in 2015, that the CPS, which had seen a 25 percent reduction in its budget over a five-year period, had reached a tipping point where services were inevitably suffering. Saunders, the then DPP, rejected these claims, stating that while there were "pressures" on the CPS, its "record of delivering justice for the public speaks for itself" (BBC Radio 4, 2015). However, in an interview upon leaving her post as DPP in October 2018, Saunders was extremely critical about "the lack of resourcing", and suggested that the criminal justice system was "creaking" (Iqbal, 2018). It is inevitable that such severe cuts would affect investigations and prosecutions. For example, individuals create an unprecedented electronic footprint these days, and this includes (but is not limited to) mobile phone location (cell site evidence), social media, emails, internet history, credit cards, and CCTV footage. Such material is timeconsuming and staff intensive, in particular when preparing the evidence for pre-trial disclosure as the police should go through this first. Under Section 3(1) of the Criminal Procedure and Investigations Act 1996 (as modified by the Criminal Justice Act 2003), there is a clear and continuing duty on the prosecution to disclose any material that "might reasonably be considered capable of undermining the case for the prosecution... or of assisting the case for the accused". Several cases indicating severe problems with pre-trial disclosure, including that of Liam Allan whose rape trial collapsed when a disc containing 40,000 messages was finally disclosed (BBC, 2018), were highlighted by the media during Saunders' time as DPP. These cases led the CPS to carry out a review of rape cases where someone had been charged and pleaded not guilty. Of the 3,637 cases reviewed, 47 were dropped on non-disclosure grounds (Davies and Dodd, 2018). It must be argued that with the knowledge of the disclosure failures, the review should not only have focused on ongoing cases. Instead, a thorough and honest review of past cases should also have been prioritised. A CIU operating independently out of (or parallel to) the CPS would have been perfectly placed to undertake such a review of charges. Furthermore, the modern society produces a lot more material for disclosure than in the past, and it must be emphasised that disclosure failures pre-trial may occur within all types of cases, not only alleged rape cases.

A back-end example of this reluctance to acknowledge the state of the criminal justice system can be seen in relation to the work by the Criminal Cases Review Commission (CCRC). Despite the recently departed chair of the CCRC, Richard Foster (in post 2008-2018), confirming that the number of applications have risen, that for every $f 10$ they had to spend ten years ago there is now only $f 4$, and that the CCRC does have money but "never quite enough", the Ministry of Justice maintains that the CCRC "has the resources to carry out its valuable work effectively" (Bowcott, 2018). Corporate publications by the CCRC have for several years pointed at problems with disclosure failings. For example, the annual report for 2016/17 stated that "a major cause of miscarriage of justice continues to be non- 
disclosure, at or before trial, of material which could have been of assistance to the defence" (CCRC, 2016/17: 3). Following the scandal that had come to light regarding pretrial disclosure mentioned above, the CCRC announced that it would review rape cases that it had closed during a two-year period (April 2016 - March 2018). Of the 306 rape cases that were identified, the CCRC has decided to only carry out a more detailed investigation on a 20 percent sample of those cases, a total of 61 cases (CCRC, 2018b). The decision to only scrutinise one fifth of the cases needs to be questioned. Pre-trial disclosure failures do not only happen in relation to rape cases, so arguably other cases should have been considered as well. This decision to only carry out a limited investigation may be due to underresourcing, but this also shows how unlikely it is for a case to pass through the CCRC process to a referral, even where pre-trial disclosure failures may have been suspected. A CIU operating within (or parallel to) the CPS would arguably be well placed to undertake a more thorough review of all of the identified rape cases, as well as additional cases where similar pre-trial disclosure failings could have been expected.

Austerity cuts over the past decade have inevitably contributed to a reduction in staff and resources, and this can in part explain the failures with pre-trial disclosure. However, postconviction access to material is virtually non-existent, and this leads to additional problems when someone is trying to appeal their conviction. This controversial issue has been known to those working at the back-end of justice for several decades. If something has not been disclosed pre-trial, chances are slim to none that it will be disclosed post-conviction. In comparison to the USA, the situation with post-conviction access in England and Wales is catastrophic. An anecdotal example of this can be seen in the Netflix documentary series Making a Murderer, where Steven Avery's team has access to virtually everything it needs to build an appeal, including video footage from the trial, physical exhibits, documents and materials. Whilst Avery's case is an example from one individual state, namely Wisconsin, and not necessarily representative of the USA as a whole, this level of access is impossible in England and Wales. Third party access to material is essential as it means that cases could be worked on more efficiently before an application to the CCRC is even made. This would reduce the costs at the CCRC level, especially as some third party actors work pro bono (e.g. innocence organisations and some lawyers) and therefore are not a burden on the shrinking Ministry of Justice budget. Considering CIUs, it is likely that third party access would be beneficial for such a system as well, depending on how such units are created and what powers they are given (whether operating in-house or independent). Access is key to efficient post-conviction review work, and it is crucial that convicted individuals and their representatives are not denied such access.

For further comparison, whereas England and Wales recklessly destroys digital audio recordings of crown court trials after seven years, in the USA court transcripts have been provided to a defendant free of charge since 1956 (see Griffin v. Illinois, 351 US 12 (1956)). The availability of court transcripts enables 'an autopsy' to be carried out on the trial after conviction. These transcripts may be scrutinised by lawyers looking for legal irregularities whereas, for example, a scientific expert may review the parts of a transcript of relevance to their expertise. It is clear that the current provisions for post-conviction access in England and Wales do not work and an overhaul of the system is needed to remove the barriers that 
have been put in place. A good start would be an immediate ban on the destruction of court transcripts. Arguably, if it is too expensive to type up transcripts and provide them for free (or for a nominal cost), convicted individuals could instead be provided with the actual audio recording, or an access code for the individual or their representatives to download it from the internet, which is not difficult in this digital age. This would enable efficient case work to be carried out before contact with the CCRC or a CIU is even made, and thus, it would help not only the convicted individual but also, in effect, any under-resourced official body working with post-conviction reviews.

Creating a CIU within each of the 14 CPS areas in England and Wales could resolve many of the problems with post-conviction access that currently plagues the jurisdiction, as reviews would be undertaken in-house, with full access, but without the additional effort and expense of screening files and redact / restrict content before disclosing anything to a third party. CIUs modelled on those in the USA could be a solution, provided they are adequately funded, resourced and staffed, and there is a genuine effort to review cases. However, in order to ensure that such CIUs are run as effectively as possible, further checks and balances may be needed. Therefore, it is worth considering whether an elected position to oversee conviction integrity from the prosecution side of criminal justice could have an equally positive impact in England and Wales as the small number of existing CIUs have already had in the USA. It is not unrealistic to consider that such an elected position could be created. For example, in 2012, England and Wales introduced publically elected Police and Crime Commissioners (PCCs). This new approach was taken in an attempt to restore public confidence in the police, and to deliver policing with better civilian oversight. In accordance with the Police Reform and Social Responsibility Act 2011, the PCCs are responsible for securing and maintaining efficient and effective local police services. Alongside the chief constables, "they set objectives for their forces in an annual police and crime plan, taking account of the Home Secretary's Strategic Policing Requirement, which outlines current national threats; allocate the funds needed to achieve these objectives; and hold forces to account on behalf of the public" (NAO, 2018: 5). Whilst there has been criticism of the system of the PCCs and the elections held in 2012 and 2016, including the lack of diversity and the conformity to party political agendas which limits any real civilian oversight of the police (see e.g. Mawby and Smith, 2017), a full discussion of this criticism is beyond the scope of this article. The PCCs, at least in theory, increased democratic governance and accountability of the police. A CIU, run by a publically elected official, would provide new oversight as decisions and steps taken by the police and the CPS (including in relation to disclosure) could be scrutinised and questioned. This would arguably strengthen the integrity of the criminal justice system as a whole. Ironically, it has been noted that the CCRC, which was created to separate post-conviction investigations from the executive, is unlikely to even refer those cases that acted as a catalyst for this change (e.g. the Birmingham Six), using the 'real possibility' test (Naughton, 2010a).

Solutions need to be found urgently in relation to the two broad themes of issues affecting those who have been wrongfully convicted in England and Wales. First, the CCRC, the body that has now been in place for over 20 years and which was created to review potential miscarriages of justice, has been accused - with good reason - of actually contributing to 
the systemic injustice facing those very people it was meant to help (see e.g. Kerrigan, 2010; Naughton, 2010a, 2010b, 2010c; Naughton, 2013). This is due in part to CCRC's underresourcing, but also due to its own decision-making processes and apparent hesitation to refer cases to the CACD. Whilst an increase in its budget can solve the under-resourcing, as demonstrated in part two, better third party access to post-conviction disclosure is arguably needed for cases to do better in the screening and decision-making processes. Secondly, whilst it would make a lot of sense to argue in favour of improved post-conviction access overall, this has been done for several decades and such suggestions have not only fallen on deaf ears - the situation has even gotten worse after Nunn (see e.g. Bolton et al., 2017; Henneberg, 2017; McCartney and Speechless, 2015).

Whether arguing for a continuation of the CCRC or a new system with CIUs in-house at the CPS, improved third party access would mean that cases could have valuable input by third parties before an application is even made. Without improving third party access however, CIUs within the 14 CPS areas may arguably be best placed to review cases post-conviction, as they are in-house and this reduces the additional expense of having to prepare files for disclosure. Conversely, a CIU placed outside of the CPS may be as dependent on improved access as any other third party, unless given powers equal to those of the CCRC or an inhouse unit when it comes to access.

It is time to start discussing alternative ways to deal with these pressing post-conviction issues. Whether or not CIUs could be useful in combination with, or as a partial replacement to, the CCRC is one option that is worth adding to the debate. Alternatively, it is worth discussing whether a de-centralised approach where CIUs could replace the CCRC altogether, in smaller offices across the country, would be beneficial.

\section{Conclusion}

Comparative criminal justice research is beneficial when critically examining policies and practices of a specific jurisdiction. However, there are limitations when comparing the single jurisdiction of England and Wales with the USA, as the latter has many individual jurisdictions that differ in the way they deal with criminal cases post-conviction. It is therefore important to be cautious about generalisations, and recognise that what applies in one state may not apply in another. In addition, there are substantial differences between England and Wales and the USA in terms of punitiveness, such as the use of the death penalty and longer prison sentences in the USA, which may explain some of the differences observed.

In any jurisdiction, a wrongful conviction seriously undermines the integrity of that criminal justice system. Most jurisdictions do give a defendant at least limited rights to appeal a conviction, however, an appeal system needs to be accessible and user friendly if it is to be of benefit to those individuals who have been failed by the system and become wrongfully convicted for a crime they did not commit. One vital factor in this is access to the files that police and prosecution have, and access to any material that would be helpful in demonstrating that the conviction was unsafe. Without proper post-conviction access, it is 
virtually impossible to get through the appeal system and have a contested conviction overturned. Whilst the blue print for the CCRC may look appealing to scholars in the USA, it needs to be recognised that the way the CCRC has worked so far does not help those who allege that they have been wrongfully convicted. Far from it. The appeal system in England and Wales urgently needs to be reformed. CIUs modelled on those in the USA may be the solution to problems relating to disclosure, both pre-trial and post-conviction, and may be a more efficient solution than the CCRC.

Having obstacles in place for access post-conviction is not only unfair to those trying to appeal, but this also harms the integrity of the criminal justice system as it appears that its decisions are beyond proper scrutiny. Finding conclusive evidence of innocence (or guilt!) strengthens the integrity of any criminal justice system, and CIUs operating out of the 14 CPS areas in England and Wales would be well placed to carry out such important work. In addition, having publically elected officials, similar to the PCCs introduced in 2012, running the CIUs would provide more civilian oversight, better democratic governance and raise the accountability within this part of criminal justice as well, as decisions made by the police and the CPS could be scrutinised and questioned. However, with both the retention of the CCRC and/or new in-house CIUs, it would be beneficial to have better third party access to postconviction disclosure, as this would not only help the individual who claims to have been wrongfully convicted, but it also alleviates pressures on stretched budgets if third parties are willing and able to work pro bono. It is recognised that a CIU that is created outside of the CPS may be wholly dependent on third party access to post-conviction disclosure too, unless given similar powers to those that the CCRC currently have. In conclusion, justice is compromised when the lack of post-conviction access effectively prevents any real chances to appeal a wrongful conviction. It must be concluded that better post-conviction disclosure overall is needed in England and Wales, but also in the USA.

\section{References}

Allison, E., Hattenstone, S., Bowcott, O., 2018. Miscarriages of justice body is not fit for purpose, lawyers say. The Guardian, 30 May 2018.

https://www.theguardian.com/law/2018/may/30/criminal-cases-review-commission-notfit-for-purpose-lawyers-say (accessed 14 December 2018).

Ashworth, A., Redmayne, M., 2010. The criminal process. Oxford University Press, Oxford.

Bandyopadhyay, S., McCannon, B.C., 2014. The effect of the election of prosecutors on criminal trials. Public Choice, Vol. 161, 141-156.

BBC., 2018. Met Police apologise for Liam Allan rape case errors. BBC, 30 January 2018. https://www.bbc.co.uk/news/uk-england-42873618 (accessed 14 December 2018). 
BBC Radio 4., 2015. File on 4 - CPS: Prosecutors on trial. BBC Radio 4, 20 September 2015. https://www.bbc.co.uk/programmes/b069vtmq (accessed 14 December 2018).

Boehm, D.C., 2014. The new prosecutor's dilemma: Prosecutorial ethics and the evaluation of actual innocence. Utah Law Review, 613-675.

Bolton, E., Burley, J., Henneberg, M., Eady, D., Shorter, L., 2017. The Open Justice Charter. Proof, No.2, 68-71.

Bowcott, O., 2015. Legal aid cuts: Lawyers to begin boycott that could see courts grind to a halt. The Guardian, 30 June 2015. https://www.theguardian.com/law/2015/jun/30/criminallawyers-promise-boycott-legal-aid-cases-lower-rate (accessed 14 December 2018).

Bowcott, O., 2017. Destruction of court records 'hampers miscarriages of justice inquiries'. The Guardian, 31 January 2017.

https://www.theguardian.com/law/2017/jan/31/destruction-of-court-records-hampersmiscarriage-of-justice-inquiries (accessed 14 December 2018).

Bowcott, O., 2018. Miscarriage of justice body's funding cuts criticised as workload grows. The Guardian, 9 September 2018. https://www.theguardian.com/law/2018/sep/09/miscarriage-of-justice-bodys-funding-cutscriticised-as-workload-grows (accessed 14 December 2018).

Burley, J., 2017. Open Justice Charter launch: 'I'd rather be wrongfully convicted in New Orleans than in New Malden. The Justice Gap, 13 January 2017.

https://www.thejusticegap.com/open-justice-charter-launch-id-rather-wrongfullyconvicted-new-orleans-new-malden/(accessed 12 December 2018).

Chandler, I.H., 2016. Conviction integrity units: Owning the past, changing the future. Criminal Justice, Summer 2016, 14-16.

CCRC., 2018a. Case statistics. https://ccrc.gov.uk/case-statistics/ (accessed 12 December 2018). 
CCRC., 2018b. Update on CCRC's review of disclosure, 21 September 2018.

https://ccrc.gov.uk/update-on-ccrcs-review-of-dislcosure/ (accessed 14 December 2018).

CCRC., 2017/18. Criminal Cases Review Commission Annual Report and Accounts 2017/18. https://s3-eu-west-2.amazonaws.com/ccrc-prod-storage-

1jdn5d1f6iq1l/uploads/2018/07/CCRC-Annual-Report-2017-18 Web-Accessible.pdf (accessed 12 December 2018).

CCRC., 2016/17. Criminal Cases Review Commission Annual Report and Accounts 2016/17. https://s3-eu-west-2.amazonaws.com/ccrc-prod-storage-

1jdn5d1f6iq11/uploads/2015/01/1096 WLT Criminal-Cases-Review-AR WebAccessibleM1.pdf (accessed 12 December 2018).

CCRC., N.D. CCRC application form. https://s3-eu-west-2.amazonaws.com/ccrc-prodstorage-1jdn5d1f6iq1l/uploads/2017/02/CCRC-Application-Form.pdf (accessed 12 December 2018).

Davies, C., Dodd, V., 2018. CPS chief apologises over disclosure failings in rape cases. The Guardian, 5 June 2018. https://www.theguardian.com/law/2018/jun/05/scores-of-uksexual-offence-cases-stopped-over-evidence-failings (accessed 12 December 2018).

Death Penalty Information Center, 2019. States with and without the death penalty (as of March 13, 2019). https://deathpenaltyinfo.org/states-and-without-death-penalty (accessed 27 April 2019).

Dodd, V., 2018. Police chiefs warn of fewer officers after treasury shrinks budget further. The Guardian, 23 October 2018. https://www.theguardian.com/uknews/2018/oct/23/police-chiefs-fewer-officers-treasury-shrinks-budgets-pensions (accessed 7 December 2018).

Duffy Rice, J., 2018. Do conviction integrity units work? The Appeal, 22 March 2018. https://theappeal.org/do-conviction-integrity-units-work-a718bbc75bc7/ (accessed 12 December 2018).

Fairfax Jr., R.A., 2012. The "smart on crime" prosecutor. The Georgetown Journal of Legal Ethics, Vol. 25, 905-912. 
Garrett, B.L., 2011. Convicting the innocent: Where criminal prosecutions go wrong. Harvard University Press, Cambridge, Massachusetts.

Gordon, S.C., Huber, G.A., 2007. The effect of electoral competitiveness on incumbent behavior. Quarterly Journal of Political Science, Vol. 2, 107-138.

Gould, J.B., Leo, R.A., 2016. The path to exoneration. Albany Law Review, 79(2), 325-372.

Green, A., 2010. Challenging the refusal to investigate evidence neglected by trial lawyers, in Naughton, M. (Ed.), The Criminal Cases Review Commission: Hope for the innocent?. Palgrave Macmillan, Basingstoke, UK, pp.46-58.

Gross, S.R., 2016. What we think, what we know and what we think we know about false convictions. Ohio State Journal of Criminal Law, Vol. 14, 753-786.

Henneberg, M.L., 2017. Worlds apart: Cold case reviews and investigations into alleged wrongful convictions in England and Wales. Journal of Cold Case Review, 3(1), 25-38.

Henneberg, M. L., 2016. 'Making a Murderer' and the limits of open justice. The Justice Gap, 4 January 2016. https://www.thejusticegap.com/making-a-murderer-and-the-limits-ofopen-justice/ (accessed 12 December 2018).

Hodgson, J., Horne, J., 2009. The extent and impact of legal representation on applications to the Criminal Cases Review Commission (CCRC). Available at SSRN: https://ssrn.com/abstract=1483721 (accessed 27 June 2019).

Hollway, J., 2016. Conviction review units: A national perspective. Public law and legal theory research paper series, research paper No. 15-41, University of Pennsylvania Law School.

Hoyle, C., 2019. Forensic science and expert testimony in wrongful convictions: A study of decision-making at the Criminal Cases Review Commission. The British Journal of Criminology, Vol. 59(4), 919-937. 
Huber, G.A., Gordon, S.C., 2004. Accountability and coercion: Is justice blind when it runs for office? American Journal of Political Science, Vol. 48, 247-263.

Innocence Project., 2015. Conviction integrity unit best practices, 15 October 2015. https://www.innocenceproject.org/wp-content/uploads/2016/09/Conviction-IntegrityUnit.pdf (accessed 12 December 2018).

Iqbal, N., 2018. Alison Saunders: 'You wouldn't be human if accusations didn't affect you. The Guardian, 27 October 2018. https://www.theguardian.com/law/2018/oct/27/alisonsaunders-outgoing-dpp-good-job-interview-cps (accessed 12 December 2018).

Justice., 2011. How to appeal: A guide to the criminal appeal system. Justice, London, UK.

Kerrigan, K., 2010. Real possibility or fat chance?, in Naughton, M. (Ed.). The Criminal Cases Review Commission: Hope for the innocent?. Palgrave Macmillan, Basingstoke, UK, pp. 166177.

Kroepsch, D., 2016. Prosecutorial best practice committees and conviction integrity units: How internal programs are fulfilling the prosecutor's duty to serve justice. The Georgetown Journal of Legal Ethics, Vol. 29, 1095-1110.

Levenson, L.L., 2014. Searching for injustice: The challenge of postconviction discovery, investigation, and litigation. Southern California Law Review, Vol. 87, 545-584.

Levenson, L.L., 2015. The problem with cynical prosecutor's syndrome: Rethinking a prosecutor's role in post-conviction cases. Berkeley Journal of Criminal Law, Vol. 20(2), 335398.

McCartney, C., Speechless, N., 2015. The Supreme Court, post-conviction disclosure and 'fishing expeditions': R(Nunn) v Chief Constable of Suffolk Constabulary \& Anor [2014] UKSC 37. The International Journal of Evidence and Proof, 19(2), 120-126. 
Moore, T., 2011. Prosecutors reinvestigate questionable evidence: Dallas establishes conviction integrity unit. Criminal Justice, 26, 4-11.

Murray, R., 2016. Disclosure rule change: Are we finally stopping the erosion of the burden of proof? The Justice Gap, 15 November 2016. https://www.thejusticegap.com/disclosurerule-change-finally-stopping-erosion-burden-proof/(accessed 12 December 2018).

National Audit Office, NAO, 2018. Financial sustainability of police forces in England and Wales 2018, 11 September 2018. https://www.nao.org.uk/wpcontent/uploads/2018/09/Financial-sustainability-of-police-forces-in-England-and-Wales2018.pdf (accessed 14 December 2018).

National Registry of Exonerations, NRE, 2018a. Detailed list. http://www.law.umich.edu/special/exoneration/Pages/detaillist.aspx (accessed 14 December 2018).

National Registry of Exonerations, NRE, 2018b. Exonerations in 2017. http://www.law.umich.edu/special/exoneration/Documents/ExonerationsIn2017.pdf (accessed 14 December 2018).

National Registry of Exonerations, NRE, 2015. Exonerations in 2014. https://www.law.umich.edu/special/exoneration/Documents/Exonerations in 2014 report .pdf (accessed 14 December 2018).

Naughton, M., 2010a. Introduction, in Naughton, M. (Ed.). The Criminal Cases Review Commission: Hope for the innocent?. Palgrave Macmillan, Basingstoke, UK, pp. 1-14.

Naughton, M., 2010b. Conclusion, in Naughton, M. (Ed.). The Criminal Cases Review Commission: Hope for the innocent?. Palgrave Macmillan, Basingstoke, UK, pp.221-228.

Naughton, M., 2010c. The importance of innocence for the criminal justice system, in Naughton, M. (Ed.). The Criminal Cases Review Commission: Hope for the innocent?. Palgrave Macmillan, Basingstoke, UK, pp.17-38. 
Naughton, M., 2010. The Criminal Cases Review Commission: Hope for the innocent?. Palgrave Macmillan, Basingstoke, UK.

Naughton, M., 2013. The innocent and the criminal justice system: A sociological analysis of miscarriages of justice. Palgrave Macmillan, Basingstoke, UK.

Pakes, F., 2015. Comparative criminal justice ( $3^{\text {rd }}$ ed.). Routledge, Abingdon, UK.

Pecker, R., 2013. Quasi-judicial prosecutors and post-conviction claims of innocence: Granting recusals to make impartiality a reality. Cardozo Law Review, Vol. 34, 1609-1648.

Roberts, S., 2017. Fresh evidence and factual innocence in the Criminal Division of the Court of Appeal. The Journal of Criminal Law, Vol. 81(4), 303-327.

Roberts, S., Weathered, L., 2009. Assisting the factually innocent: The contradictions and compatibility of innocence projects and the Criminal Cases Review Commission. Oxford Journal of Legal Studies, Vol. 29(1), 43-70.

Robins, J., 2016. "We deserve a justice system that is open and transparent". The Justice Gap, 15 January 2016. https://www.thejusticegap.com/12251/ (accessed 14 December 2018).

Robins, J., 2018a. Miscarriages watchdog blames drop in referrals on 'low success rate' in Court of Appeal and lack of lawyers willing to take cases on. The Justice Gap, 6 July 2018. https://www.thejusticegap.com/miscarriage-watchdog-blames-drop-in-referrals-on-lowsuccess-rate-in-court-of-appeal-and-lack-of-lawyers-willing-to-take-cases-on/ (accessed 12 December 2018).

Robins, J., 2018b. \#The Law Is Broken. New Law Journal, 11 May 2018. https://www.newlawjournal.co.uk/content/law-broken (accessed 26 June 2019).

Saunders, J., 2014. The Kevin Nunn case and the Catch 22s facing wrongly accused. The Justice Gap, 23 May 2014. https://www.thejusticegap.com/case-kevin-nunn-catch-22wrongly-accused/ (accessed 14 December 2018). 
Scheck, B., 2010. Professional and conviction integrity programs: Why we need them, why they will work, and models for creating them. Cardozo Law Review, Vol. 31, 2215-2256.

Scheck, B.C., 2017. Conviction integrity units revisited. Ohio State Journal of Criminal Law, Vol. 14, 705-752.

Tonry, M., 2012. Prosecutors and politics in comparative perspective. Crime and Justice, Vol. 41, 1-33.

Ware, M., 2012. Dallas County conviction integrity unit and the importance of getting it right the first time. New York Law School Law Review, Vol. 56, 1033-1050.

Welch, M., 2011. Corrections: A critical approach ( $3^{\text {rd }}$ ed.). Routledge, Abingdon, UK.

This research did not receive any specific grant from funding agencies in the public, commercial, or not-for-profit sectors. 